\title{
The history of neuromyelitis optica
}

\author{
Sven Jarius ${ }^{*}$ and Brigitte Wildemann
}

\begin{abstract}
The discovery of a novel serum autoantibody (termed NMO-IgG or AQP4-Ab) in a subset of patients in 2004 has revived interest in neuromyelitis optica (NMO). While the history of classical multiple sclerosis has been extensively studied, only little is known about the history of NMO. In the present article, we provide a comprehensive review of the early history of this rare but intriguing syndrome. We trace the origins of the concept of NMO in the 19th century medical literature and follow its evolution throughout the 20th and into the 21st century. Finally, we discuss recent proposals to revise the concept of $\mathrm{NMO}$ and explain why there is indeed a need for a more systematic and descriptive nomenclature.
\end{abstract}

Keywords: Neuromyelitis optica, Devic's syndrome, Devic's disease, Myelitis, Optic neuritis, Multiple sclerosis, Nomenclature, Diagnostic criteria, History of neurology

\section{Introduction}

Neuromyelitis optica (NMO) is a rare condition, characterized by myelitis and optic neuritis, which shares a number of clinical and radiological features with multiple sclerosis (MS) [1-3]. The groundbreaking discovery of a novel, pathogenic autoantibody (termed NMO-IgG or AQP4-Ab) in a subset of patients by Dr Lennon and colleagues in $2004[4,5]$ has led to a tremendous increase in interest in NMO. NMO-IgG/AQP4 antibody-positive $\mathrm{NMO}$ is now considered a disease entity in its own right rather than a subtype of MS.

While the history of classical MS has been studied extensively, only little is known about the history of NMO. In the present article, we comprehensively review the early history of NMO. We trace the first accounts of this peculiar term in the 19th century French-, English-, and German-language literature and follow its definition's meandering evolution throughout the 20th and into the 21 st century. Finally, we will discuss recent proposals to re-define or substitute the term and explain why there is indeed a need for a more systematic and descriptive nomenclature.

\footnotetext{
*Correspondence: sven.jarius@med.uni-heidelberg.de Division of Molecular Neuroimmunology, Department of Neurology, University of Heidelberg, Im Neuenheimer Feld 450, Heidelberg 69120, Germany
}

\section{Eugène Devic and Fernand Gault}

'Neuromyelitis optica acuta' and the more rarely used English equivalent 'acute optic neuromyelitis' are both translations of the French term 'neuro-myélite optique aiguë, which was first used by Eugène Devic (1858-1930) in a paper communicated on the occasion of the Congrès Français de Médecine in Lyon in 1894 (Figures 1 and 2). Devic intended the term to denote a novel syndrome characterized by acute myelitis and optic neuritis: 'Ces seize cas de myélite aiguë accompagnés de névrite optique sont suffisants pour légitimer la création d'un type clinique, ou plutôt d'un syndrome auquel on pourrait donner le nom de neuro-myélite optique' [6].

The same year, Devic's student Fernand Gault (18731936) published his doctoral thesis, entitled De la neuromyélite optique aiguë (Figure 3), which consisted of a review of the previous medical literature and a clinicopathological analysis of Devic's case [7]. (The fact that the congress proceedings with Devic's abstract appeared only in 1895 , i.e. after Gault's thesis, has given rise to some confusion in the literature. However, Devic gave his presentation on Friday, 26th October 1894; by contrast, Gault's thesis was printed only in November 1894 according to the imprint, and its dedication is dated ' 20 novembre 1894')

We will never know with absolute certainty whether it was Devic or Gault who originally invented the term; however, the following lines from Gault's thesis strongly suggest it was indeed Devic: 'Bien que l'axiome « Il n'y a 


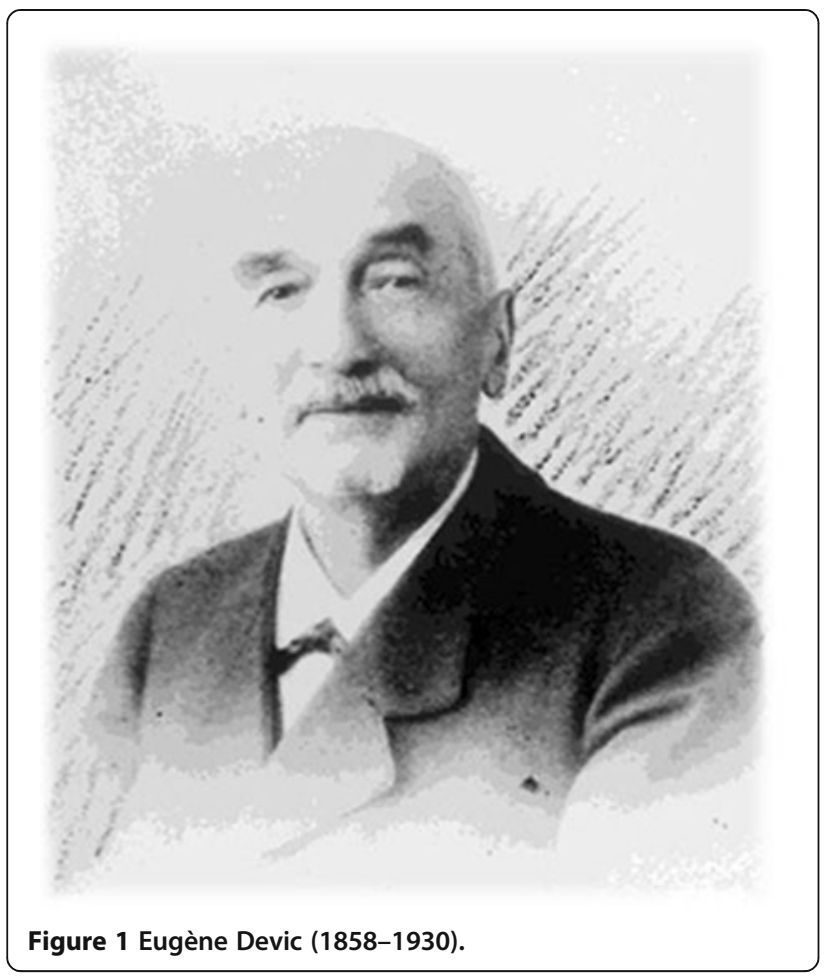

pas de maladies, il n'y a que des malades » soit toujours vrai, il est certain cependant que, quand on parvient à réunir en un syndrome un ensemble constant de symptômes, il est certain, dis-je, que l'on peut proposer un nom servant à désigner le cas type, et sur les conseils de M. le Dr Devic, je propose celui de neuro-myélite diffuse, aiguë' [7].

There is some evidence that the term 'neuro-myélite' was chosen by Devic and Gault in analogy with 'neurocérébrite', a term associated with the name of August Pierret. Pierret, a pupil of Charcot and at that time professor at the Clinique des maladies mentales at Lyon,

M. E. Devra, de Lyon. - Myélite aiguë dorso-lombaire avec névrite optique. - Autopsie.

Femme de 45 ans, migraincuse el nerveuse, ayant ou pluxieurs crises d'hystérie pendanl sa jeunesse. Ni maladies infectieuses récentes, ni intoxication professionnelle, pas d'alcoolisme, pas de syphílis. En juin 1890 , son mari tombe gravement malaclo, cllo le soigue pentant six mois avec un grand dévouement, nassant la plus grande partic des nuits. I meurt en décembre de la mòme anncie. Profonlément affectéo de cette mort, ayant dóponsó ses dernières économies, olle dut se remettre à un travail peu rémunérateur, autant du moins quo le lui permit l'apparition de sympitòmes neurasthéniques bien caractérisés: insomnic, troubles digestifs, asthénio neuro-musculaire, palpitations ot surtout céphalée. Ces symptònes augmontèrent peu à peu d'intensitśet en septembre 1892 la malade dut cesser tout travail. En noveunbre 1892 la faiblesse génćrale et la cépbalée subirent une recrudescence notable sous l'infuenco d'une vive frayeur.

Figure 2 Heading and first paragraph of Eugène Devic's famous abstract for the Congrès Français de Médecine in Lyon in 1894.

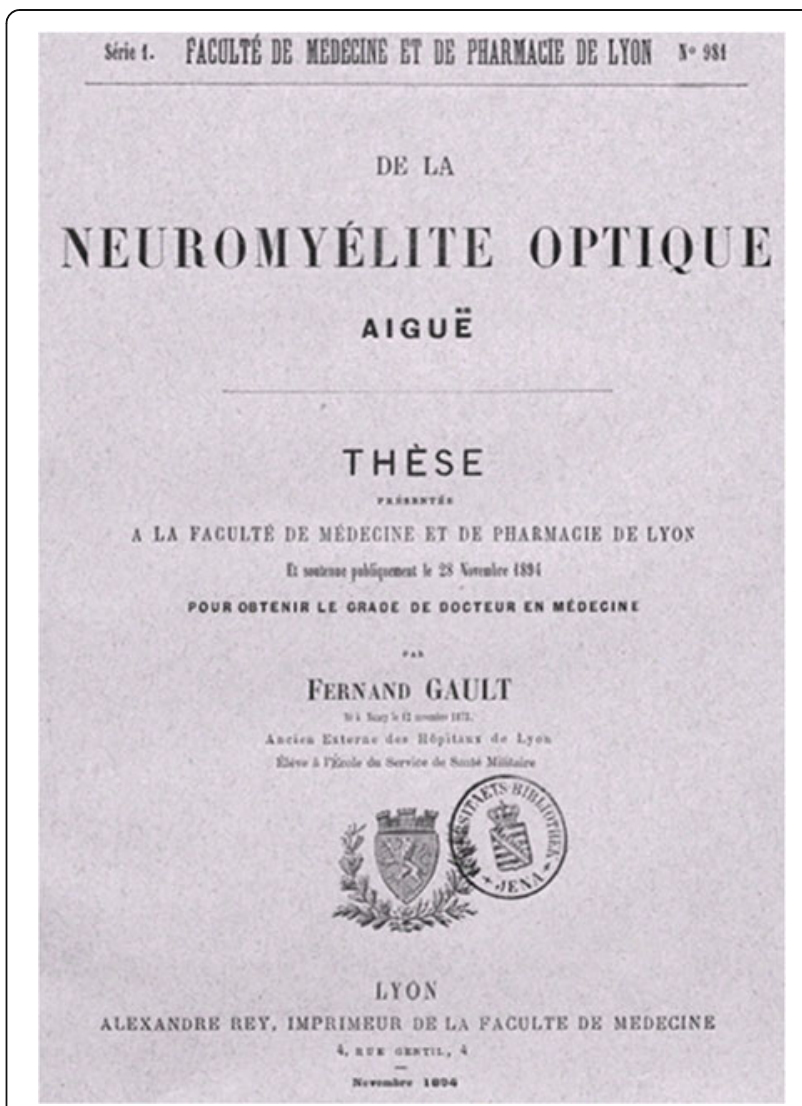

Figure 3 Title page of Fernand Gault's doctoral thesis De la neuromyélite optique aiguë (Lyon, November 1894).

was president of the examination board committee responsible for Gault's thesis. Moreover, Gault's thesis was dedicated to Pierret, and its very last sentence reads: 'Ce syndrome relève probablement dans un certain nombre de cas de l'infection. C'est un exemple nouveau d'un processus infectieux, frappant à la fois deux points éloignés du système nerveux sans qu'il y ait de lésions anatomiques quelconques reliant ces deux foyers. A ce titre, ce syndrome mérite d'être rapproché de la neurocérébrite de M. le professeur Pierret' [7].

(In 1935, the Berlin neurologist Erwin Stengel would make an attempt to resuscitate Pierret's term in a paper on a series of patients with neuritis cranialis and accompanying brainstem encephalitis, in which he proposed to refer to such cases by the term 'neuro-encephalitis'. Interestingly, one of his patients had optic neuritis, and Stengel wrote: 'Der Fall, bei dem auch eine Neuritis optica bestand, könnte in Analogie zur Bezeichnung Neuromyelitis optica als Neuroencephalitis optica [italics ours] bezeichnet werden' [8]. Recent studies have shown that brainstem involvement is quite common in patients with AQP4 autoimmunity, and cases of AQP4 antibodypositive 'neuroencephalitis optica' without concomitant myelitis indeed occur [1,9]. - A very early account of 
possible 'neuroencephalitis optica' is to be found in the in the second, enlarged edition (1829) of John Abercrombie's (1780-1844) Pathological and Practical Researches on Diseases of the Brain and Spinal Cord, a case of intractable vomiting, relapsing visual loss, and spinal pain $[10,11]$; intractable vomiting and hiccups are typical manifestations of medulla oblongata involvement in aquaporin4 antibody-positive $\mathrm{NMO}$ and often herald the onset of myelitis [12,13]).

While several articles on Devic's life have been published, only little is known about Gault's biography. According to Politzer's monumental Geschichte der Ohrenheilkunde, Gault worked as an army doctor following his graduation from the Lyon faculty in 1894, but soon became professor of otorhinolaryngology at the Medical School in Dijon (in 1905) and head of the ENT department there in 1911 [14]. We traced more than 20 publications authored or coauthored by Gault; however most of them were dedicated to ENT topics. It seems that Gault never again published on NMO. He died in 1936, just six years after Devic.

\section{NMO before Devic and Gault}

As recently shown by us [10,15-17], Devic and Gault in their reviews overlooked some early cases of possible NMO, probably owing to the restricted bibliographic resources of the time (both Devic's and Gault's lists of references were mainly based on that of an earlier German review by the Dresden-based ophthalmologist Fritz Schanz [18], as conceded by Devic in reference [19]). In 1844 , i.e. 26 years prior to the first case referenced by Devic and Gault, the Genoese physician Giovanni Battista Pescetto (1806-1884) had reported on a 42-yearold man who simultaneously developed acute amaurosis and cervical myelitis, with complete recovery following extensive bloodletting [10]; in 1850, the British physician Christopher Mercer Durrant (1814-1901) had described a case of tetraparesis and (partly reversible) bilateral amaurosis in the precursor of the British Medical Journal [20]; and in 1862 the British neuroanatomist, neuropathologist, and neurologist Jacob Augustus Lockhart Clarke (1817-1880), known to many as the eponym of Clarke's column, the posterior thoracic nucleus, had reported the case of a 17-year-old girl with bilateral optic neuritis and longitudinally extensive transverse myelitis in The Lancet [15]. Finally, a report by Antoine Portal (1742-1832), first physician to Louis XVIII and founding and lifelong president of the Académie Nationale de Médecine, deserves to be mentioned here: it represents the first account of visual loss in a patient with spinal cord inflammation but no brain pathology in the Western literature known so far [16]. However, none of these previous authors had ever used the term 'neuromyelitis optica' or a similar one.

\section{Peppo Acchioté}

In 1907, Peppo Acchioté (1870-1916; the original Turkish spelling is Pe(p)po Akşiyote or Akşiyoti (Kirbaş, 2003)), a physician from Constantinople, 'spécialiste pour les maladies nerveuses et sur l'électrothérapie' [21], proposed for the first time - in a paper communicated by no less a figure than Joseph Babinski (1857-1932) on 4th July 1907 on the occasion of a session of the Société de Neurologie de Paris - to make Devic the eponym of NMO: 'Lassociation de névrite optique avec une myélite diffuse constitue l'affection denommée par M. Devic, de Lyon, neuromyélite optique aiguë et qu'il serait plus juste, à mon avis, de designer sous le nom de maladie de Devic' [22].

In this paper, Acchioté also reported on a case of his own, a 25-year-old woman with bilateral optic neuritis, paraparesis, and sensory and sphincter disturbances.

In choosing the term 'maladie', Acchioté deviated from Devic's original definition of NMO as a 'syndrome' or 'type clinique' [6]. This deviation has consequences to our day, as we will discuss below. It should not go unmentioned, however, that Acchioté's choice of the word 'maladie' has in fact some foundation in Gault's thesis. While Devic originally described NMO as a 'syndrome' or 'type clinique', Gault was more ambiguous. While he defined 'NMO', following Devic, as a 'syndrome' or 'complexus symptomatique' in the final conclusion of his thesis - characterized by bilateral optic neuritis (simultaneously or alternately), usually resulting in complete yet mostly transient amaurosis (with possible full functional recovery), and diffuse or localized acute myelitis, with the latter mostly following the optic nerve affliction - he wrote in the introduction to his thesis: 'Le syndrome dont nous voulons parler constitue cependant une entité morbide [italics ours] bien distincte et ayant droit de cité dans le cadre nosologique' [7]. Elsewhere in his paper, Acchioté used the more neutral French term 'affection' [22].

Little is known about Acchioté's life. According to Dursun Kirbaş's History of Turkish Neurology (Türkiye Nöroloji Tarihçesi), Acchioté (Figure 4) studied in Paris [23]. We could identify a proceeding that lists him as a visiting physician at the Service des enfants idiots, épileptiques et arriérés at the Bicêtre in 1903 [21]. Later, he was a member of the teaching staff at the Istanbul Civilian Medical School and, at least from 1910 on, assistant professor at the Neurology Department of the Haydarpaşa Medical Faculty, as deputy to Raşit Tahsin, a pupil of Kraepelin, Binswanger, and Mendel, and one of the pioneers in neurology in Turkey [24].

Given that numerous case reports and at least two reviews $[11,19]$ on the association of myelitis and amaurosis were published prior to Devic and Gault, Acchiotés proposal may be considered another example of what Robert Merton (rather playfully) once called the palimpsestic (or anatopic) syndrome, which is not so rare a 


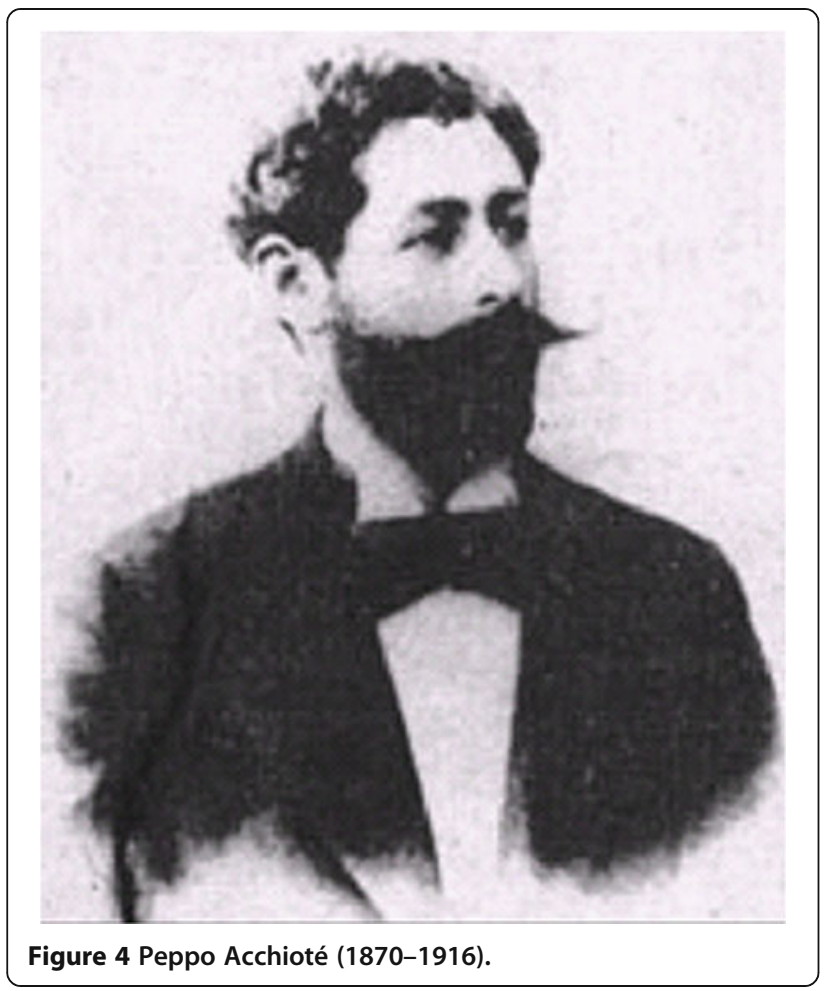

phenomenon in the history of medicine: 'the altogether innocent transmitter becomes identified as the originator of the idea when his merit lies only in having kept it alive $(. .$.$) or perhaps in having put it to new or instruct-$ ive use' [20]. That said, not mentioning Devic and Gault's unique contribution would mean committing what Merton called the 'sin of adumbrationism' [20]: While others had in fact reported on NMO before, it was they who gave it a name - and '[w]hat is a disease before it gets a name?' (T. Jock Murray, Multiple Sclerosis: The History of a Disease, New York, 2005).

Acchiotés proposal was soon made known to a broader audience by the reprinting of his paper in the Revue neurologique [25] and by a short summary that appeared later the same month in the Annales d'oculistique [26].

Some authors have proposed to revise Acchiotés eponymous designation to acknowledge also Gault's important contribution to the history of NMO $[27,28]$.

\section{'NMO': early accounts in the non-French literature}

Devic never used the neoclassical adaption 'neuromyelitis optica' widely preferred today. The earliest use of that version we could trace is found in a 1904 German-language review by the Austrian psychiatrist Erwin Stransky [29], a pioneer in research on schizophrenia (for a brief sketch of Stransky's disturbing biography see ref. [30]). In this article, Stransky summarized and discussed a report by the French pathologist and neurologist Édouard Brissaud, a pupil of Charcot and Lasègue, about a 16-year-old boy with NMO, which had appeared in the Revue Neurologique earlier the same year [31].

The first two uses of the English-language term 'acute optic neuromyelitis', and at the same time the first account of a variant of 'NMO' in any language other than French we could find, were in a September 1903 issue of the British Medical Journal [32], in an anonymous review of Weill and Gallavardin's case in the Lyon Medicale [33] (an exact reprint of that review appeared in the December 1903 issue of The Ophthalmoscope [34]), and in a short review by Hugh T. Patrick, Professor of Neurology at Northwestern University, of the same French report in the 10th volume of the 1904 edition of the Practical Medicine Series of Year Books, which appeared the same month [35]. Also in 1904, Gowers' authoritative textbook on the ophthalmoscopic signs of neurological diseases appeared in a revised edition [36]. However, Gowers, who was well aware of the still relatively rare reports on the coincidence of optic neuritis and acute myelitis and who had taken part in the early discussions regarding the pathogenic relationship between these two afflictions, did not adopt the term 'neuromyelitis' in this or, to the best of our knowledge, in any other of his writings.

While most later authors writing in English and German would use the neoclassical term (rare exceptions are Perrit [37] and Vernant et al. [38]), local spellings ('neuromielite ottica' and 'neuromielitis óptica', respectively) were used in some of the early Italian- $[39,40]$ and Spanish-language [41] publications on NMO, and Devic's original version has remained prevalent in the French-language literature to this day.

\section{Alternative denominations}

In his communication, Devic proposed 'neuropticomyélite' as an alternative denomination. However, this term has not been widely adopted by neurologists (rare exceptions are to be found in Bouchut and Dechaume [42], and Euzière and Bremond [43]). In his thesis, Gault once used the term 'neuro-myélite diffuse aigüe'; which refers to 'myélite diffuse' but, surprisingly, makes no mention of the optic nerve. Other rare variants used in a handful of publications include 'neuro-optic myelitis' [44], 'neurópticomielitis aguda' [45], 'neuropticomielitis' [41], 'opthalmoneuromyélite' [46-48], 'oftalmomielitis' [41], and 'mielitis oftálmica' [41].

\section{Etymology}

Evidently, 'neuromyelitis optica' and 'neuropticomyelitis' are artificial composites of myelitis, i.e. inflammation of the spinal cord, and 'neuritis (cranialis) optica', a problematic (strictly speaking, a neuritis cannot be 'optical'; however, as a sort of constructio ad sensum, some may nevertheless consider that expression acceptable) and, accordingly, not 
widely used (a famous exception is Wilhelm Erb's early description of NMO, which was entitled Über das Zusammenvorkommen von Neuritis optica und Myelitis subacuta [49]; see also Noyes [50]) alternative to the more correct term 'neuritis nervi optici', i.e. inflammation of the optic nerve. Etymologically, they are combining forms of the An-

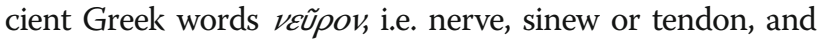
$\mu v \varepsilon \lambda o ́ \varsigma$, i.e. marrow (probably a derivative of $\mu v \omega \dot{v}$, muscle), the post-classical Latin word optica, and the suffix -itis, which was already used in Greek to indicate disease (though not necessarily inflammation). As 'neuropticomyelitis' is a Greek-Latin hybrid and because 'optic myelitis' does not, strictly speaking, make much sense, purists might regard these terms as linguistic barbarism [51]. However, such classical compounds are common in medical terminology with its strong need for classification and, in consequence, distinguishing denominations; accordingly, the term was widely accepted and has survived to our days.

Previous usage of the term 'neuromyelitis': Dunglison and Hildenbrand

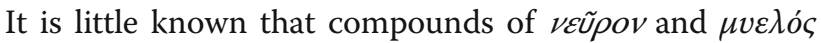
had been in existence before Devic's time. The 1836 edition of the prestigious Dictionnaire de l'Académie Française defined 'névromyélite' as 'inflammation de la moelle épinière' and, thus, as a synonym of 'myélite'. However, we did not find evidence in the medical literature of the time that the term thus defined was widely used; instead, it seems to have led a lonely existence in that dictionary as a hapax legomenon. The same holds true for the (etymologically corrupt) definition of 'neuro-myelitis' as inflammation of the vertebra in an 1875 Italian dictionary [52]. However, the etymological explanations given above indicate that the term 'neuromyelitis' may also be used (and perhaps with more justification from a linguistic point of view) to refer to inflammation of the medulla nervorum. In fact, the word was defined in Robley Dunglison's (then widely used) 19th century Medical Lexicon exactly in this sense: 'NEUROMYELI'TIS, from vevpov, "a nerve", $\mu v \varepsilon \lambda o s$, "marrow", and itis, denoting inflammation. Inflammation of the medullary matter of the nerves'. This definition is first documented in the 1848 edition of that early Dictionary of Medical Science (as its subtitle reads), and we found it in a number of (later) German dictionaries as well (cf. Ernst Gabler, Lateinisch-deutsches Wörterbuch für Medicin und Naturwissenschaften, Berlin, 1857: 'Neuromyelitis, die Entzündung des Nervenmarks. Neuromyelos, das Nervenmark', Wilhelm Probstmayr, Etymologisches Wörterbuch der Veterinär-Medicin und ihrer Hilfswissenschaften, Munich, 1863: 'Neuromyelitis (...), die Entzündung des Nervenmarks = Inflammatio medullae nerveae').

One of the few accounts of the term 'neuromyelitis' as defined by Dunglison (or, more exactly, 'nevromyelitis') and at the same time the earliest one we are aware of - in the medical literature is to be found in the third volume of Johann Valentin Hildenbrand's famous Institutiones practico-medicae (published posthumously by his son in 1822) [53] (Figure 5). Hildenbrand (1763-1818) used the term to distinguish inflammation of the pulpa nervorum from that of the vagina nervorum, to which he referred as 'nevrilemmatitis': 'Longe obscurius incedit phlogosis pulpae nervosae (Nevromyelitis); confunduntur enim tunc phaenomena, quae inflammationem in genere denotare solent, plurimum imperfecte evoluta, cum symptomatibus nervosis hyperaesthesiam, vel spasmum indicantibus' [53]. Another early instance is to be found in Ernst von Grossi's Familiarum morborum humanorum expositio: 'inflammatio medullae nervae diversae seu neuromyelitis' [54].

The presence of a vagina nervorum as opposed to the medulla was already recognized by earlier authors (who,

\section{VALENTINI NOBLIS AB HLLENBRAND,}

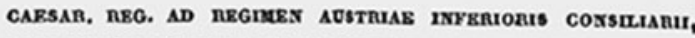
PRAXEOS CLISICAE IX UXIVEnsitate vispoBoxersi pnoFkssonis, DIRECTORIS XOSOCOMU UNIVERSALIS, BREPHOTROPIEI ETC.

\section{INSTITUTIONES}

\section{PRACTICO MEDICAE.}

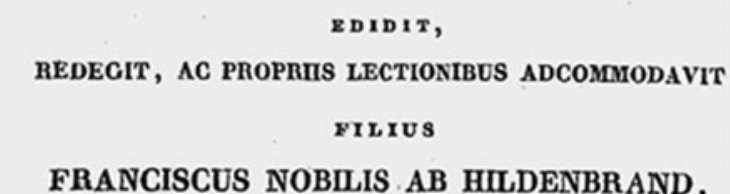

IED. DOCT. AnTIS OCOLARIAE MAGISTER, PRAXEOS CLIXICAK IX USIYENSITATE TICIKENSI PROYESSOR, DIRECTOR XOSOCOMI oxIYERSAL1S, BREPHOTROPHEI ETC.

TOMUS TERTIUS.

coxrixexs:

DOCTRINAM dE FBBRIBUS INFLAMMATORIS COMITATIS, xx INFLAMMATIONIBUS TOPICIS IN SPECIE.

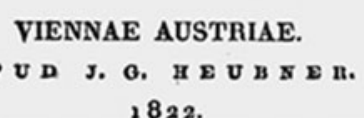

Figure 5 Title page of the third volume of Johann Valentin Hildenbrand's Institutiones practico-medicae (Vienna, 1822; published posthumously). 
though, did not use the term 'nevromyelitis') as reviewed by Georg Prohaschka in his 1779 De Structura Nervorum: Tractatus Anatomicus Tabulis Aeneis Illustratus (see Section I, caput V). However, these early authors (as well as some of the later ones, e.g. Joseph Hyrtl, Lehrbuch der Anatomie des Menschen, 1857: 'Das Neurilemm enthält die Ernährungsgefässe des Nerven, und führt sie seinen Bündelabtheilungen $\mathrm{zu}^{\prime}$ ) rather had in mind the connective tissue (epi-, peri-, and endoneurium) investing the nerves, nerve fascicles, and nerve fibres. It was not until 1838/39 that Schwann identified the cell type that commemorates his name, and Ranvier would still bemoan the lack of knowledge and confusion in the nomenclature regarding the nerve sheaths in 1872 .

This distinction was soon criticized by Pierre Adolphe Piorry (1794-1879), one of the fathers of percussion and inventor of the plessimeter, as artificial and lacking experimental evidence: 'A plus forte raison en est-il ainsi du diagnostic qu'on a voulu établir entre la névromyélite et la névrilemmite [italics ours]. (...) [I]l aurait bien mieux valu la répéter, et, jusqu'à temps qu'on fasse voir le névrilemme d'un filet nerveux enflammé indépendamment de sa pulpe, et vice versa, il sera permis de ne pas croire à ces distinction subtiles qui, à coup sûr, ne sont pas nées d'observations cliniques rigoureuses' [55]. In 1850, Piorry would repeat his harsh criticism, arguing that the difference would be of little therapeutic consequence: 'C'est une chose curieuse que de voir l'assurance avec la quelle Boisseau et d'autres pathologistes établissent des caractères distinctifs de la névrilèmite et de la névrite qu'ils appellent aussi névromyélite. (...) au point de vue pratique a bien peu d'importance. Nous ne voyons pas en effet, quelles seraient les différences à établir sous le rapport du traitement entre la phlegmasie d'un nerf et celle de son enveloppe' [56].

Piorry's article was published in 1833 in his Clinique médicale de l'hôpital de la Pitié et de l'hospice de la Salpétrière [55] and reprinted in the Gazette médicale [57]. English translations appeared soon after in the American Journal of the Medical Sciences [58] and in The Western Journal of the Medical and Physical Sciences [59]; these translations represent the first uses of the term 'neuromyelitis' (N.B.: not 'neuromyelitis optica'!) we could trace in the Englishlanguage literature. Before Piorry, François Gabriel Boisseau (1791-1836) had made the distinction in nomenclature between 'névrilemmite' and 'névromyélite' already in 1830 in his Nosographie organique [60], which we believe is the first French account: 'Quand le névrilème seul est enflammé (névrilemmite), (...) Quand la substance médullaire du nerf est elle-même enflammée (névromyélite)' (see also Pierre Joseph Mongellat, Monographie des irritations intermittentes, Bruxelles, 1839: 'isoler l'inflammation du nerf (névrite), de celle du névrilème (névrilémite ou névrilite), et de celle encore de la pulpe nerveuse (névromyélite)', with reference to Boisseau).
An anonymous review of Hildenbrand's Institutiones in the Medicinisches Jahrbuch des kaiserlichen königlichen Österreichischen Staates for 1837 ('Entzündung (...) der Nervenhäute, nevrolemitis, nevrymenitis, der Nervensubstanz nevromyelitis, gangliitis') is the first account in the German-language literature [61].

Hildenbrand, who coined the term 'neuromyelitis', may still be known to some as the eponym of Hildenbrand's disease, that is typhus (see the back references to ICD-9-CM 081.9). Coincidentally, of all diseases it was Hildenbrand's disease from which Peppo Acchioté, originator of the term 'Devic's disease', was to die in 1916 [23].

One might accuse us of having overlooked that Piorry referred to Johann Christian Reil (1759-1813) when criticizing the above-mentioned distinction, not to Hildenbrand. Reil, physician to Goethe and appreciated by many as the father of modern psychiatry, was among the first to point to the possibility of inflammation of the nerves by the demonstration of vasa nervorum in his seminal Exercitationum Anatomicarum Fasciculus Primus / De Structura Nervorum, Halle, 1796. Reil also provided a very detailed description of the anatomy of the nerve and its sheaths. In the fourth volume of his main work Ueber die Erkenntni $\beta$ und Kur der Fieber, Vienna, 1802, which is dedicated to feverish nervous diseases, he indeed distinguished afflictions of the Neurilem from those of the nervous Mark. However, Piorry's comment leads us astray. A meticulous search of both Reil's German and Latin writings failed to locate a single mention of the term in question. It is therefore likely that Piorry, when referring to Reil's concept, used the terminology of his own time. - Like Acchioté, Reil too died from Hildenbrand's disease.

\section{Thomas Clifford Allbutt}

Thomas Clifford Allbutt (1836-1925) is still known to many as the inventor of the clinical thermometer and to neurologists and ophthalmologists as the main instigator (alongside Gowers) of the clinical use of the ophthalmoscope. In his famous lecture On the Ophthalmoscopic Signs of Spinal Disease [62], Allbutt very briefly mentioned a patient with acute myelitis and 'a sympathetic eye disorder'. This case was long considered the first account of a patient with NMO in the literature. We recently re-discovered a more detailed description of that patient tucked away in the appendix of Allbutt's textbook on the use of the ophthalmoscope $[17,63]$. While Allbutt might not have been the first to report on a case of NMO (see above and reference [17]), it was certainly his report that created the sustained interest of neurologists and ophthalmologists in this rare syndrome.

Often, the palimpsestic syndrome mentioned above is caused by what has been called the Matthew effect: 'unto every one that hath shall be given' (Matthew 25:29, King James Version). The incorrect (as we know today) 
attribution of primacy in relating a case of NMO to Allbutt in so many articles in the field might - given that author's exceptional reputation and social status (the list of titles held by Allbutt included K.C.B., M.A., M.D., LL.D., D.Sc., F. R.C.P., F.R.S., F.L.S., F.S.A. and Regius Professor of Physic at the University of Cambridge) - indeed represent a true example of that effect. 'Devic's disease', by contrast, is the exception that proves the rule: While Devic became an eponym, pioneers of modern neurology or ophthalmology who were probably better known than Devic at that time and had published on NMO before [11,14], such as Clarke, Allbutt, Erb, or Knapp, came out empty-handed in this case.

Allbutt never used the term 'neuromyelitis optica'. As a curious coincidence, however, of all authors Allbutt might have been the first to use the term 'neuromyelitis' in a medical text in a way distinct from Hildenbrand's definition. He did so in an address entitled On the Surgical Aids to Medicine delivered at the inaugural meeting of the Midland Medical Society on 19th October 1881 [64], in which he referred to the discussion on surgical 'nerve stretching' that had taken place at the International Medical Congress in August the same year (for the rationale of that unusual procedure see Allbutt's System of Medicine (1901): 'When all else fails, nerve stretching or even excision of a portion of the nerve must be tried. The amount of tension brought to bear on the nerve should be sufficient at least to lift the limb off the table. One advantage is the breaking down of adhesions, which in a small percentage of cases may have something to do with the pain; but the main advantage is counter-irritation very directly applied.'; cf. also John Marshall, Neurectasy, or, Nerve-stretching for the relief or cure of pain: being the Bradshaw Lecture delivered at the Royal College of Surgeons on the 6th of December 1883, with an appendix, Smith, Elder, and Co, London, 1887). In that address Allbutt concluded that 'nerve stretching (...) is the only remedy which offers much hope of relief to sufferers from the pains of chronic neuro-myelitis'. Although Allbutt did not provide an exact definition, he explicitly referred to patients with pain and 'spinal disease' [italics ours].

\section{'Ascending neuromyelitis'}

For the sake of completeness, it should not go unmentioned that the term 'neuromyelitis' was used by some authors to refer to Landry's paralysis, and the World Health Organization's International Classification of Diseases still lists the term 'ascending neuromyelitis' among the synonyms of 'Guillain-Barre syndrome' (ICD 61.0). A very rare variant is 'neuromyelitis hyperalbumenotica' [65].

\section{'NMO' in the 20th century: the same term, but evolving concepts}

The past 120 years have seen many different criteria for the diagnosis of $\mathrm{NMO}$, and, consequently, the exact meaning (and, in particular, the extension) of the term 'NMO' has changed over the years. Some criteria excluded (unnecessarily, as we know today) patients with a relapsing course [66-68], a long interval between the two index events myelitis and neuritis [66-68], only mild para- or tetraparesis [69], incomplete myelitis [69], or unilateral optic neuritis [66-68]. Although Devic and Gault had already pointed to the fact that some patients may develop symptomatic brainstem lesions, some criteria also excluded patients with symptoms other than optic neuritis and myelitis [2,66,70,71] (more recent studies have proven Devic and Gault right $[1,9])$. Others proposed excluding patients with co-existing systemic lupus erythematosus (SLE) or Sjögren's syndrome (SS) [70]. However, AQP4-Ab-positive NMO was recently shown to be frequently associated with other autoimmune disorders, in particular SLE and SS [1,72-77]. Finally, some criteria considered spinal cord lesions extending over more than two vertebral segments (as measured by MRI) to be a prerequisite for a diagnosis of NMO [70]. However, recent studies showed that short lesions occasionally occur $[1,78]$. Similarly, brain lesions on MRI were considered atypical for NMO in the past; later studies, however, demonstrated that (mostly asymptomatic) brain lesions indeed occur in around 60\% of patients with $\mathrm{NMO}$, are sometimes present already at onset, and may occasionally even meet MRI criteria for MS $[1,79,80]$.

\section{NMO and MS: a difficult relationship}

The question of the exact relationship between NMO and classical multiple sclerosis (MS) has engaged neurologists for more than a century. While Devic and Gault believed that, 'des raisons suffisantes pour empêcher d'admettre qu'à aucun moment des lésions aient pu jamais prendre l'apparence anatomique de la sclérose en plaques' [7], others considered NMO a subtype of MS. For example, Russell Brain, in his famous 1930 review on MS and NMO, concluded that the clinical and pathological differences between neuromyelitis optica and disseminated sclerosis appear to be differences of acuteness and intensity only (...) there seems no justification for separating them' [81]. Only the discovery of pathogenic antibodies to aquaporin- 4 in a subset of patients with NMO but not MS and the demonstration of corresponding pathological differences [4,82-87] has led to the recognition of 'NMO-IgG-positive NMO' as an immunopathologically defined disease entity in its own right distinct from classical MS.

All those restrictions in the definition of what the term 'NMO' should signify discussed above rested on the need to differentiate NMO and MS solely on the basis of clinical and radiological findings. With the availability of AQP4-IgG, it became possible to distinguish the two 
conditions on the basis of laboratory findings. This resulted in a change of perspective, which for the first time permitted appreciation of the partial overlap between NMO and MS in terms of clinicoradiological presentation and, in consequence, broadened substantially the meaning attached to the term 'NMO'.

While clinical and radiological features remain highly relevant when it comes to distinguishing seronegative NMO from MS (unless a specific laboratory marker for either of these two conditions is found), the broadening spectrum of syndromes reported associated with AQP4IgG renders it likely that future diagnostic criteria for seropositive NMO will put less emphasis on clinicoradiological findings but rather on strict laboratory standards (this could include the requirement to confirm test results in a second - and, if discrepant, a third -, methodologically independent immunoassay with high specificity and sensitivity as already recommended in current guidelines for other autoantibody mediated diseases of the CNS).

\section{NMO: disease or syndrome?}

The recent progress in our understanding of the pathogenesis of NMO brought about by the breakthrough discovery of AQP4-Ab has challenged the traditional usage of the term 'NMO'.

Neglecting the large number of reports on cases of possible rheumatic, (para)infectious, paraneoplastic, metabolic, or toxic aetiology, some of which even date back to the time of Devic and Gault, NMO was for a long time treated by many as a disease entity rather than a syndrome, as reflected by the widely applied term 'Devic's disease' (or 'Morbus Devic', a variant used mainly, but not exclusively, in the German-language medical literature).

However, the lack of AQP4-IgG-seropositivity in a subset of patients even in the most up-to-date, recombinant assays, and in particular the demonstration of such a lack in some patients with $\mathrm{NMO}$ and conditions that may cause myelitis and optic neuritis by other mechanisms, e.g. connective tissue disorders [72], paraneoplastic disorders [88,89], or infectious diseases [90], has provided strong evidence in favour of the hypothesis of NMO being aetiopathogenetically heterogeneous. Importantly, some of these assays have been shown to be capable of detecting AQP4-Ab even in samples taken during remission and under treatment with strong immunosuppressants such as rituximab, azathioprine, mitoxantrone, or cyclophosphamide, practically ruling out the possibility that seronegativity is generally the result of insufficient assay sensitivity [1,91-93]). The notion of aetiopathological heterogeneity is further supported by the recent demonstration of significant clinical and paraclinical differences between seropositive and seronegative patients [1] and the finding of antibodies to myelin oligodendrocyte glycoprotein in some AQP4-Ab-negative patients [94-96].

Nonetheless, the current diagnostic criteria still subsume AQP4-IgG-seropositive and -AQP4-IgG-seronegative cases under the same disease heading, i.e. 'NMO' [78]. Employing common criteria and a common designation for seropositive and seronegative NMO may be useful when it comes to differentiating NMO from MS (the lack of oligoclonal bands in most patients with seronegative NMO indicates that the latter is not simply a clinicoradiological subtype of MS but is of distinct pathogenesis [1]); however, this might be problematic when it comes to treating patients with NMO: While the demonstration of a pathogenic effect of AQP4-IgG provides a strong rationale for B cell- and antibody-targeted treatments in AQP4-IgG-seropositive NMO $[97,98]$, so far there is less strong evidence of a role for B cells and pathogenic autoantibodies in the majority of patients with seronegative NMO.

Based on the current concept of NMO being aetiologically heterogeneous (and unless this concept is formally disproved, which is unlikely to happen), the term 'Devic's disease' should be avoided and replaced by 'Devic's syndrome'. Accordingly, we believe that the term 'NMO' should no longer be used as a disease designation; instead, it should be used exclusively to refer to a clinical phenotype or syndrome (characterized by optic neuritis and myelitis).

\section{'NMO spectrum disorder(s)'}

Another problem attached to the current nomenclature results from the recent finding that the spectrum of clinical manifestations of AQP4 autoimmunity is wider than previously thought and includes (1) various forms of brainstem encephalitis in adults; (2) a broad variety of cerebral symptoms in children; and (3) abortive forms such as isolated longitudinally extensive transverse myelitis or isolated optic neuritis, which in NMO-IgGpositive patients often convert to NMO [1,9,92,99-104]. Some authors proposed tackling this problem by introducing the term 'NMO spectrum disorder' ('NMO-SD'), a designation which was intended to be used to refer to all major clinical manifestations that had by then been reported in association with NMO-IgG.

Unfortunately, however, this potentially useful concept [103] has been employed inconsistently in the literature:

1) Some authors use 'NMO-SD' as an abbreviation for 'NMO spectrum disorder' (note that 'disorder' is used in the singular here) and thereby refer to a shared underlying pathogenesis; by contrast, others defined 'NMO-SD' as 'NMO spectrum disorders' (note the plural) and thereby refer to a spectrum of clinico-radiological manifestations

2) Among those who understand 'NMO-SD' as a spectrum of clinico-radiological manifestations, some 
include $\mathrm{NMO}$, while others explicitly use the term 'NMO-SD' exclusively to refer to manifestations other than NMO

3) Finally, some authors refer only to NMO-IgGpositive cases, while others apply the term both to NMO-IgG-positive and to NMO-IgG-negative cases

A more stringent use of the term 'NMO-SD' would be desirable in order to make it easier to compare results between studies. Moreover, it should be taken into account that while most patients with NMO-IgG-positive myelitis, optic neuritis or brainstem encephalitis later convert to NMO, most NMO-IgG-negative patients do not $[99,101,104]$. Accordingly, labelling all such patients with the term 'NMO-SD' is somewhat problematic.

\section{'Autoimmune AQP4 channelopathy'}

As alternative designations, recently terms based on immunopathology such as 'autoimmune AQP4 channelopathy' or 'autoimmune AQP4 disease' have been proposed [106-108]. We consider these suggestions useful. These terms could be employed whenever reference is made to the common pathogenenesis thought to underlie the AQP4-IgG-positive cases. We would like to add the term AQP4(-Ab-associated) encephalomyelitis' as another proposal. This term would be in line with an already established nomenclature that classifies cases of autoimmune encephal(omyel)itis according to the patients' autoantibody status (e.g. NMDAR encephalitis, anti-Hu-associated encephalomyelitis); moreover, including the word 'encephalitis' would take into account (1) that the brain is more often affected than previously thought and (2) that the optic nerve is anatomically part of the encephalon.

\section{Towards a descriptive and systematic nomenclature}

However, for clinical purposes, as well as in the context of clinical studies and treatment trials, neither a classification solely based on common pathogenesis ("AQP4 channelopathy/encephalomyelitis") nor the (ambiguous) concept of NMO-SD seems completely sufficient; rather, a more differentiated, descriptive and systematic classification that reflects an individual patient's exact clinical phenotype, antibody status, and disease course might be required, for the following reasons:

First, certain clinical features, laboratory findings, and/ or prognostic characteristics differ between AQP4-IgGpositive and AQP4-IgG-negative patients $[1,99,101,104$, 109], among the various NMO-SD (as shown for timeto-relapse, prognostic implications of clinical presentation at onset, and CSF findings $[1,110])$, and between patients with monophasic disease and patients with relapsing disease $[1,2]$.

Second, treatment strategies might differ between AQP4IgG-positive and AQP4-IgG-negative patients (taking into account possible differences in aetiology and pathogenesis), even among NMO-SD (e.g. based on differences as to time-to-relapse and short-term prognosis [1]), and between patients with monophasic and patients with relapsing NMO-SD (which could well be manifestations of different diseases, e.g. postinfectious ADEM vs. AQP4 autoimmunity).

Third, recommendations on diagnostic AQP4-IgG testing may differ between patients with monophasic and patients with relapsing disease as well as between the various NMO-SDs: given the low frequency of AQP4-IgG in patients with a first attack of isolated optic neuritis $[97,98]$ or atypical, isolated brainstem manifestations on the one hand and the limited specificity of some of the currently available immunoassays on the other hand, general screening for AQP4-IgG in all NMO-SD patients entails the risk of an unfavourably high ratio of false-positive to truepositive results and may therefore not be advisable.

Such descriptive nomenclature would distinguish between $\mathrm{AQP} 4-\mathrm{Ab}$-positive $\mathrm{NMO}$ and AQP4-Ab-negative NMO, $\mathrm{AQP} 4-\mathrm{Ab}$-positive and AQP4-Ab-negative (longitudinally extensive) myelitis, AQP4-Ab-positive and AQP4-Abnegative optic neuritis, AQP4-Ab-positive and AQP4-Abnegative brainstem encephalitis, etc. In addition, the disease course (monophasic/first attack, relapsing) should be specified and information should be provided regarding co-existing autoimmunity as well as regarding the suspected aetiology in seronegative patients.

\section{Conclusion and outlook}

The nomenclature of NMO and its atypical and abortive forms is complex. Its meandering evolution and this complexity reflect the ongoing endeavours by generations of neurologists to facilitate distinction of this rare condition from MS and other related conditions, all the while making room for improvements in diagnosis and in our understanding of the pathogenesis of NMO.

Clear classifications are not a pure academic exercise but a crucial prerequisite for future treatment trials. Our paper aims to fuel the ongoing discussion about the need for new diagnostic criteria for NMO and revisions in nomenclature. We hope that the proposals set out herein will help to solve some of the issues attached to the current nomenclature.

\section{Abbreviations}

NMDAR: N-Methyl-D-aspartate receptor; NMO-SD: Neuromyelitis optica spectrum disorder(s); SLE: systemic lupus erythematosus; SS: Sjögren's syndrome;

ADEM: Acute disseminated encephalomyelitis; AQP4-Ab: Aquaporin-4 antibodies; CNS: Central nervous system; CSF: Cerebrospinal fluid; IgG: Immunoglobulin G; LETM: Longitudinally extensive transverse myelitis; MRI: Magnetic resonance imaging; MS: Multiple sclerosis; NMO: Neuromyelitis optica.

\section{Competing interests}

The authors declare that they have no competing interests. 


\section{Authors' contributions}

SJ conceived and designed the study, collected and analysed the data, and drafted the manuscript. BW was involved in revising the manuscript for important intellectual content. Both authors read and approved the final manuscript.

\section{Acknowledgements}

The work of SJ was supported by a Fellowship from the European Committee for Research and Treatment in Multiple Sclerosis (ECTRIMS). The work of BW was supported by research grants from Merck Serono and Bayer HealthCare.

Received: 23 November 2012 Accepted: 7 December 2012 Published: 15 January 2013

\section{References}

1. Jarius S, Ruprecht K, Wildemann B, Kuempfel T, Ringelstein M, Geis C, Kleiter I, Kleinschnitz C, Berthele A, Brettschneider J, Hellwig K, Hemmer B, Linker RA, Lauda F, Mayer CA, Tumani H, Melms A, Trebst C, Stangel M, Marziniak M, Hoffmann F, Schippling S, Faiss JH, Neuhaus O, Ettrich B, Zentner C, Guthke K, Hofstadt-van Oy U, Reuss R, Pellkofer H, et al: Contrasting disease patterns in seropositive and seronegative neuromyelitis optica: a multicentre study of 175 patients. I Neuroinflammation 2012, 9:14

2. Wingerchuk DM, Hogancamp WF, O'Brien PC, Weinshenker BG: The clinical course of neuromyelitis optica (Devic's syndrome). Neurology 1999, 53:1107-1114.

3. Kitley J, Leite MI, Nakashima I, Waters P, McNeillis B, Brown R, Takai Y, Takahashi T, Misu T, Elsone L, Woodhall M, George J, Boggild M, Vincent A, Jacob A, Fujihara K, Palace J: Prognostic factors and disease course in aquaporin-4 antibody-positive patients with neuromyelitis optica spectrum disorder from the United Kingdom and Japan. Brain 2012, 135:1834-1849.

4. Lennon VA, Kryzer TJ, Pittock SJ, Verkman AS, Hinson SR: IgG marker of optic-spinal multiple sclerosis binds to the aquaporin-4 water channel. J Exp Med 2005, 202:473-477

5. Lennon VA, Wingerchuk DM, Kryzer TJ, Pittock SJ, Lucchinetti CF, Fujihara K Nakashima I, Weinshenker BG: A serum autoantibody marker of neuromyelitis optica: distinction from multiple sclerosis. Lancet 2004 364:2106-2112.

6. Devic E: Myélite aiguë dorso-lombaire avec névrite optique. - Autopsie. In Congrès français de médecine (Premiere Session; Lyon, 1894; procès-verbaux, mémoires et discussions; publiés par M. le Dr L. Bard). Paris: Lyon: Asselin et Houzeau, Louis Savy; 1895:434-439.

7. Gault F: De la neuromyélite optique aiquë. Thése: Faculté de Médecine et de Pharmacie; 1894

8. Stengel E: Über eine Gruppe von Krankheitsfällen mit Affektionen des Hirnstamms, kombiniert mit peripherer Hirnnervenläsion (Neuroencephalitis). Z Neurol 1935, 137:221-237.

9. Pittock SJ, Weinshenker BG, Lucchinetti CF, Wingerchuk DM, Corboy JR, Lennon VA: Neuromyelitis optica brain lesions localized at sites of high aquaporin 4 expression. Arch Neurol 2006, 63:964-968.

10. Jarius $S$, Wildemann B: 'Noteomielite' accompanied by acute amaurosis (1844). An early case of neuromyelitis optica. J Neurol Sci 2012, 313:182-184.

11. Abercrombie J: Pathological and Practical Researches on Diseases of the Brain and Spinal Cord. 1st edition. Edinburgh: Waugh and Innes; 1828

12. Takahashi T, Miyazawa I, Misu T, Takano R, Nakashima I, Fujihara K, Tobita M, Itoyama Y: Intractable hiccup and nausea in neuromyelitis optica with anti-aquaporin-4 antibody: a herald of acute exacerbations. J Neurol Neurosurg Psychiatry 2008, 79:1075-1078.

13. Apiwattanakul M, Popescu BF, Matiello M, Weinshenker BG, Lucchinetti CF, Lennon VA, McKeon A, Carpenter AF, Miller GM, Pittock SJ: Intractable vomiting as the initial presentation of neuromyelitis optica. Ann Neurol 2010, 68:757-761.

14. Politzer A: Geschichte der Ohrenheilkunde. Band II: 1850-1911. Stuttgart: Ferdinand Enke; 1913.

15. Jarius S, Wildemann B: An early case of neuromyelitis optica: on a forgotten report by Jacob Lockhart Clarke, FRS. Mult Scler 2011, 17:1384-1386.
16. Jarius S, Wildemann B: The case of the Marquis de Causan (1804): an early account of visual loss associated with spinal cord inflammation. J Neurol 2012, 259:1354-1357.

17. Jarius S, Wildemann B: On the contribution of Thomas Clifford Allbutt F.R.S., to the early history of neuromyelitis optica. J Neurol 2013, 260:100-104.

18. Schanz F: Ueber das Zusammenvorkommen von Neuritis optica und Myelitis acuta. DMW 1893, 19:615-617.

19. Devic E: Myélite subaiguë compliquée de névrite optique. Le Bulletin Médicale 1894, 8:1033-1034.

20. Jarius S, Wildemann B: An early British case of neuromyelitis optica (1850). BMJ 2012, 345:e6430.

21. Anonymous: Visites du service. Recherches cliniques et thérapeutiques sur l'épilepsie, I'hystérie et l'idiotie 1904, 24:61.

22. Acchiote P: Sur un cas de neuromyélite subaiguë ou maladie de Devic. Bulletin officiels de la Société de neurologie de Paris 1907, 8-9:273-275.

23. Kirbaş D: Türkive Nöroloji Tarihçesi. Istanbul-Ekim:; 2003.

24. Dinç G, Etker Ş: Türkiye çocuk hekimliğinin ilk dergisi: La Pédiatrie en Turquie / Türkiye'de Emrâzi-Etfâl. Osmanlı Bilimi Araştırmaları 2004 5:62-101.

25. Acchiote P: Sur un cas de neuromyélite subaiguë ou maladie de Devic. Rev Neurol 1907, 15:775-777.

26. Acchiote P: Sur un cas de neuromyélite subaiguë ou maladie de Devic. Ann Ocul 1907, 70th year:374.

27. Izar G: How to diagnose Devic-Gault syndrome. Minerva Med 1960, 51:3349-3351

28. Pryse-Phillips W: Companion to Clinical Neurology. Oxford: Oxford University Press; 2009.

29. Stransky E: 22) Neuromyèlite optique aiguë, par E. Brissaud et Brécy (Review neurologique. 1904. Nr. 2.). Neurologisches Centralblatt 1904 23:823-824

30. Angetter D: Erwin Stransky: Mitbegründer der modernen Schizophrenielehre. In Österreichisches Biographisches Lexikon (online version), January 2012 edition. Vienna: Österreichische Akademie der Wissenschaften; 2012.

31. Brissaud E, Brecy N: Neuromyélite optique aigue. Rev Neurol 1904, 12:49-54.

32. Anonymous: Acute optic neuromyelitis. Br Med J 1903, 2:37-38

33. Weill $M$, Gallavardin M: Sur un cas de neuromyélite optique aiguë. Lyon Med 1903, 101:207-209.

34. Anonymous: Acute optic neuromyelitis. The Ophthlamoscope 1903, 1:230-231.

35. Patrick HT: (Ed): Acute optic neuromyelitis. Chicago, IL: The Year Book Publishers; 1904

36. Gowers WR: A manual and atlas of medical ophthalmoscopy. London: J. \& A. Churchill; 1904.

37. Perrit RA: Optic neuromyelitis: report of two cases. Arch Ophthal 1934, 11:492-497

38. Vernant JC, Cabre P, Smadja D, Merle H, Caubarrere I, Mikol J, Poser CM: Recurrent optic neuromyelitis with endocrinopathies: a new syndrome. Neurology 1997, 48:58-64.

39. Salvati G: Contributo allo studio della neuromielite ottica. Giorn Ocul 1928, 9:73.

40. Salvati G: Neuromielite ottica. Arch di ottal 1931, 38:310.

41. de Gispert Cl: Enfermedad de Devic. An Med Cir 1949, 26:116-119.

42. Bouchut L, Dechaume J: Étude histopathologique d'un cas de neuropticomyélite aiguë. Ann d'Anat Path 1927, 4:357-372

43. Euzière $P$, Bremond R: À propos d'un cas de neuropticomyélite. Rev d'otoneuro-opht 1927, 5:129-132.

44. Kohut H, Richter RB: Neuro-optic myelitis: a clinicopathological study of two related cases. J Nerv Ment Dis 1945, 101:99-104.

45. Fernandez GJ, Castells CE: La neurópticomielitis aguda (Enfermedad de Devic). Anales del instituto de neurologia (Facultad de Medicina de Montevideo) 1944, 6-7:193-231.

46. De Lapersonne F: Le syndrome de la névrite optique associée à la myélite ophthalmo-neuromyélite. Rev Neurol (Paris) 1911, 21:378-381.

47. Marinesco G, Draganesco S, Sager O, Grigoresco D: Sur une forme particulière anatomoclinique d'opthalmo-neuromyélite. Rev Neurol (Paris) 1930, 53:193-228

48. Sager O, Grigorescu D: Beiträge zum Studium der Ophthalmoneuromyelitis und ihrer Beziehungen zur disseminierten Encephalomyelitis. Eur Arch Psychiatry Clin Neurosci 1933, 98:378-387.

49. Erb W: Ueber das Zusammenvorkommen von Neuritis optica und Myelitis subacuta. Arch Psychiatr Nervenkr 1880, 10:146-157. 
50. Noyes HD: Acute myelitis mit doppelseitiger Neuritis optica. Archiv für Augenheilkunde 1881, X:331-337.

51. Kraus LA: Kritisch-etymologisches medicinisches Lexikon. 2nd edition. Wien: Anton v. Haykul and Michael Lechner; 1831.

52. Lanzillotti-Buonsanti N, Pini G: Dizionario delle science mediche e veterinarie. Milano: Vallardi; 1875

53. Hildenbrand JV: Institutiones practico-medicae. Tomus tertius. Continens: Doctrinam de febribus inflammatoriis comitatis, et inflammationibus topicis in specie. Vienna: Heubner; 1822.

54. von Grossi E: Familiarum morborum humanorum expositio. Stuttgart, Tuebingen, Munich: J. G. Cottae; 1831

55. Piorry PA: Clinique médicale de l'hôpital de la Pitié (Service de la Faculté de Médecine) et de l'hospice de la Salpétrière en 1832. Paris, London: J. B. Baillière; 1833.

56. Piorry PA: Traité de médecine pratique et de pathologie iatrique ou médicale. Paris: Baillièr; 1850

57. Piorry PA: Mémoire sur les névralgies et sur leur traitement. Gaz Méd 1833, 1:93-95.

58. Piorry PA: Remarks upon the nature of Neuralgias, and their treatment. Am J Med Sci 1834, 14:245-249.

59. Piorry PA: Remarks upon the Nature of Neuralgias, and their treatment. The Western Journal of the Medical and Physical Sciences 1835, Second hexade, Vol. II (Vol. VIII):130-137.

60. Boisseau FG: Nosographie organique. Tome quatrieme. Paris and London: J. B. Bailliere; 1830.

61. Anonymous: In Medicinische Jahrbücher des k. k. Österreichischen Staates. 22nd edition. Edited by von Raimann JNE. Vienna: Carl Gerold; 1837.

62. Allbutt TC: On the ophthalmoscopic signs of spinal disease. Lancet 1870, 95:76-78.

63. Allbutt TC: On the use of the ophthalmoscope in diseases of the nervous system and of the kidneys; also in certain other general disorders. London and New York: Macmillan and Co.; 1871.

64. Allbutt TC: An address on the surgical aids of medicine. Br Med J 1882, 1:1-5.

65. Baker AB, Baker LH: Clinical neurology. Hagerstown, MD: Harper \& Row; 1979.

66. Kuroiwa Y, Igata A, Itahara K, Koshijima S, Tsubaki T: Nationwide survey of multiple sclerosis in Japan. Clinical analysis of 1,084 cases. Neurology 1975, 25:845-851.

67. Kuroiwa Y, Hung TP, Landsborough D, Park CS, Singhal BS: Multiple sclerosis in Asia. Neurology 1977, 27:188-192.

68. Kira J: Multiple sclerosis in the Japanese population. Lancet Neurol 2003, 2:117-127.

69. O'Riordan Jl, Gallagher HL, Thompson AJ, Howard RS, Kingsley DP, Thompson EJ, McDonald WI, Miller DH: Clinical, CSF, and MRI findings in Devic's neuromyelitis optica. J Neurol Neurosurg Psychiatry 1996, 60:382387.

70. Miller DH, Weinshenker BG, Filippi M, Banwell BL, Cohen JA, Freedman MS, Galetta SL, Hutchinson M, Johnson RT, Kappos L, Kira J, Lublin FD, McFarland HF, Montalban X, Panitch H, Richert JR, Reingold SC, Polman CH: Differential diagnosis of suspected multiple sclerosis: a consensus approach. Mult Scler 2008, 14:1157-1174.

71. Silbermann SJ: Devic's disease: A clinical review and case report. J Nerv Ment Dis 1945, 102:107-120.

72. Jarius S, Jacobi C, de Seze J, Zephir H, Paul F, Franciotta D, Rommer P, Mader S, Kleiter I, Reindl M, Akman-Demir G, Seifert-Held T, Kristoferitsch W, Melms A, Wandinger KP, Wildemann B: Frequency and syndrome specificity of antibodies to aquaporin-4 in neurological patients with rheumatic disorders. Mult Scler 2011, 17:1067-1073.

73. Wandinger KP, Stangel $M$, Witte $T$, Venables $P$, Charles $P$, Jarius $S$, Wildemann B, Probst C, Iking-Konert C, Schneider M: Autoantibodies against aquaporin- 4 in patients with neuropsychiatric systemic lupus erythematosus and primary Sjogren's syndrome. Arthritis Rheum 2010, 62:1198-1200

74. Kay CS, Scola RH, Lorenzoni PJ, Jarius S, Arruda WO, Werneck LC: NMO-IgG positive neuromyelitis optica in a patient with myasthenia gravis but no thymectomy. J Neuro/ Sci 2008, 275:148-150.

75. Jarius S, Paul F, Franciotta D, de Seze J, Munch C, Salvetti M, Ruprecht K, Liebetrau M, Wandinger KP, Akman-Demir G, Melms A, Kristoferitsch W, Wildemann B: Neuromyelitis optica spectrum disorders in patients with myasthenia gravis: ten new aquaporin-4 antibody positive cases and a review of the literature. Mult Scler 2012, 18:1135-1143.
76. Jarius S, Paul F, Ruprecht K, Wildemann B: Low vitamin B12 levels and gastric parietal cell antibodies in patients with aquaporin-4 antibody-positive neuromyelitis optica spectrum disorders. J Neurol 2012, 259:2743-2745.

77. Pittock SJ, Lennon VA, de Seze J, Vermersch P, Homburger HA, Wingerchuk DM, Lucchinetti CF, Zephir H, Moder K, Weinshenker BG: Neuromyelitis optica and non organ-specific autoimmunity. Arch Neurol 2008, 65:78-83.

78. Wingerchuk DM, Lennon VA, Pittock SJ, Lucchinetti CF, Weinshenker BG: Revised diagnostic criteria for neuromyelitis optica. Neurology 2006, 66:1485-1489.

79. Pittock SJ, Lennon VA, Krecke K, Wingerchuk DM, Lucchinetti CF, Weinshenker BG: Brain abnormalities in neuromyelitis optica. Arch Neurol 2006, 63:390-396.

80. Kim JE, Kim SM, Ahn SW, Lim BC, Chae JH, Hong YH, Park KS, Sung JJ, Lee KW: Brain abnormalities in neuromyelitis optica. J Neurol Sci 2011, 302:43-48.

81. Brain WR: Critical review: disseminated sclerosis. QJM 1930, 23:343-391.

82. Roemer SF, Parisi JE, Lennon VA, Benarroch EE, Lassmann H, Bruck W, Mandler RN, Weinshenker BG, Pittock SJ, Wingerchuk DM, Lucchinetti CF: Pattern-specific loss of aquaporin-4 immunoreactivity distinguishes neuromyelitis optica from multiple sclerosis. Brain 2007, 130:1194-1205.

83. Misu T, Fujihara K, Kakita A, Konno H, Nakamura M, Watanabe S, Takahashi T, Nakashima I, Takahashi H, Itoyama Y: Loss of aquaporin 4 in lesions of neuromyelitis optica: distinction from multiple sclerosis. Brain 2007, 130:1224-1234.

84. Kale N, Pittock SJ, Lennon VA, Thomsen K, Roemer S, McKeon A, Lucchinetti CF: Humoral pattern II multiple sclerosis pathology not associated with neuromyelitis Optica lgG. Arch Neurol 2009, 66:1298-1299.

85. Yanagawa K, Kawachi I, Toyoshima Y, Yokoseki A, Arakawa M, Hasegawa A, Ito T, Kojima N, Koike R, Tanaka K, Kosaka T, Tan CF, Kakita A, Okamoto K, Tsujita M, Sakimura K, Takahashi H, Nishizawa M: Pathologic and immunologic profiles of a limited form of neuromyelitis optica with myelitis. Neurology 2009, 73:1628-1637.

86. Bruck W, Popescu B, Lucchinetti CF, Markovic-Plese S, Gold R, Thal DR, Metz I: Neuromyelitis optica lesions may inform multiple sclerosis heterogeneity debate. Ann Neurol 2012, 72:385-394.

87. Jarius S, Franciotta D, Bergamaschi R, Wright H, Littleton E, Palace J, Hohlfeld R, Vincent A: NMO-IgG in the diagnosis of neuromyelitis optica Neurology 2007, 68:1076-1077.

88. Ducray F, Roos-Weil R, Garcia PY, Slesari J, Heinzlef O, Chatelain D, Toussaint $P$, Roullet $E$, Honnorat J: Devic's syndrome-like phenotype associated with thymoma and anti-CV2/CRMP5 antibodies. J Neurol Neurosurg Psychiatry 2007, 78:325-327.

89. Jarius S, Wandinger KP, Borowski K, Stoecker W, Wildemann B: Antibodies to CV2/CRMP5 in neuromyelitis optica-like disease: case report and review of the literature. Clin Neurol Neurosurg 2012, 114:331-335.

90. Sellner J, Hemmer B, Muhlau M: The clinical spectrum and immunobiology of parainfectious neuromyelitis optica (Devic) syndromes. J Autoimmun 2010, 34:371-379.

91. Jarius S, Aboul-Enein F, Waters P, Kuenz B, Hauser A, Berger T, Lang W, Reindl M, Vincent A, Kristoferitsch W: Antibody to aquaporin-4 in the longterm course of neuromyelitis optica. Brain 2008, 131:3072-3080.

92. Jarius S, Probst C, Borowski K, Franciotta D, Wildemann B, Stoecker W, Wandinger KP: Standardized method for the detection of antibodies to aquaporin- 4 based on a highly sensitive immunofluorescence assay employing recombinant target antigen. J Neurol Sci 2010, 291:52-56.

93. Jarius S, Franciotta D, Paul F, Bergamaschi R, Rommer PS, Ruprecht K, Ringelstein M, Aktas O, Kristoferitsch W, Wildemann B: Testing for antibodies to human aquaporin-4 by ELISA: Sensitivity, specificity, and direct comparison with immunohistochemistry. J Neurol Sci 2012, 320:32-37.

94. Mader S, Gredler V, Schanda K, Rostasy K, Dujmovic I, Pfaller K, Lutterotti A, Jarius S, Di Pauli F, Kuenz B, Ehling R, Hegen H, Deisenhammer F, AboulEnein F, Storch MK, Koson P, Drulovic J, Kristoferitsch W, Berger T, Reindl M: Complement activating antibodies to myelin oligodendrocyte glycoprotein in neuromyelitis optica and related disorders. J Neuroinflammation 2011, 8:184.

95. Kitley J, Woodhall M, Waters P, Leite MI, Devenney E, Craig J, Palace J, Vincent A: Myelin-oligodendrocyte glycoprotein antibodies in adults with a neuromyelitis optica phenotype. Neurology 2012, 79:1273-1277.

96. Rostasy K, Mader S, Hennes E, Schanda K, Gredler V, Guenther A, Blaschek A, Korenke C, Pritsch M, Pohl D, Maier O, Kuchukhidze G, Brunner-Krainz M, Berger T, Reindl M: Persisting myelin oligodendrocyte glycoprotein antibodies in aquaporin-4 antibody negative pediatric neuromyelitis optica. Mult Scler 2012, doi:10.1177/1352458512470310. Dec 20 [Epub ahead of print]. 
97. Jarius S, Paul F, Franciotta D, Waters P, Zipp F, Hohlfeld R, Vincent A, Wildemann B: Mechanisms of disease: aquaporin-4 antibodies in neuromyelitis optica. Nat Clin Pract Neurol 2008, 4:202-214.

98. Jarius $\mathrm{S}$, Wildemann B: AQP4 antibodies in neuromyelitis optica: diagnostic and pathogenetic relevance. Nat Rev Neurol 2010, 6:383-392.

99. Jarius S, Frederikson J, Waters P, Paul F, Akman-Demir G, Marignier R, Franciotta D, Ruprecht K, Kuenz B, Rommer P, Kristoferitsch W, Wildemann $B$, Vincent A: Frequency and prognostic impact of antibodies to aquaporin-4 in patients with optic neuritis. J Neurol Sci 2010, 298:158-162.

100. Petzold A, Pittock S, Lennon V, Maggiore C, Weinshenker BG, Plant GT: Neuromyelitis optica-lgG (aquaporin-4) autoantibodies in immune mediated optic neuritis. J Neurol Neurosurg Psychiatry 2010, 81:109-111.

101. Weinshenker BG, Wingerchuk DM, Vukusic S, Linbo L, Pittock SJ, Lucchinetti $C F$, Lennon VA: Neuromyelitis optica IgG predicts relapse after longitudinally extensive transverse myelitis. Ann Neurol 2006, 59:566-569.

102. McKeon A, Lennon VA, Lotze T, Tenenbaum S, Ness JM, Rensel M, Kuntz NL, Fryer JP, Homburger H, Hunter J, Weinshenker BG, Krecke K, Lucchinetti CF, Pittock SJ: CNS aquaporin-4 autoimmunity in children. Neurology 2008, 71:93-100.

103. Jarius S, Lauda F, Wildemann B, Tumani H: Steroid-responsive hearing impairment in NMO-lgG/aquaporin-4-antibody-positive neuromyelitis optica. J Neurol 2012, doi:10.1007/s00415-012-6755-4. Nov 21 [Epub ahead of print]

104. Matiello M, Lennon VA, Jacob A, Pittock SJ, Lucchinetti CF, Wingerchuk DM, Weinshenker BG: NMO-IgG predicts the outcome of recurrent optic neuritis. Neurology 2008, 70:2197-2200.

105. Wingerchuk DM, Lennon VA, Lucchinetti CF, Pittock SJ, Weinshenker BG: The spectrum of neuromyelitis optica. Lancet Neurol 2007, 6:805-815.

106. Lennon VA: Changing concepts in CNS demyelinating disorders: autoimmune water channelopathies. In Program and abstracts of the American Academy of Neurology 58th Annual Meeting; 1-8 April 2006. San Diego, CA: Plenary session; 2006.

107. Wingerchuk DM: Neuromyelitis optica: new findings on pathogenesis. Int Rev Neurobiol 2007, 79:665-688.

108. Matsushita T, Isobe N, Matsuoka T, Shi N, Kawano Y, Wu XM, Yoshiura T, Nakao Y, Ishizu T, Kira Jl: Aquaporin-4 autoimmune syndrome and antiaquaporin-4 antibody-negative opticospinal multiple sclerosis in Japanese. Mult Scler 2009, 15:834-847.

109. Akman-Demir G, Tuzun E, Waters P, Icoz S, Kurtuncu M, Jarius S, Yapici Z, Mutlu M, Yesilot N, Vincent A, Eraksoy M: Prognostic implications of aquaporin-4 antibody status in neuromyelitis optica patients. J Neurol 2011, 258:464-470.

110. Jarius S, Paul F, Franciotta D, Ruprecht K, Ringelstein M, Bergamaschi R, Rommer P, Kleiter I, Stich O, Reuss R, Rauer S, Zettl UK, Wandinger KP, Melms A, Aktas O, Kristoferitsch W, Wildemann B: Cerebrospinal fluid findings in aquaporin-4 antibody positive neuromyelitis optica: results from 211 lumbar punctures. J Neurol Sci 2011, 306:82-90.

\section{Submit your next manuscript to BioMed Central and take full advantage of:}

- Convenient online submission

- Thorough peer review

- No space constraints or color figure charges

- Immediate publication on acceptance

- Inclusion in PubMed, CAS, Scopus and Google Scholar

- Research which is freely available for redistribution 